漢方学術講演会報告

\title{
各種湿疹に対する十味敗毒湯の治療効果** \\ Clinical Effect of Jumihaidokuto (Tsumura) on Eczema
}

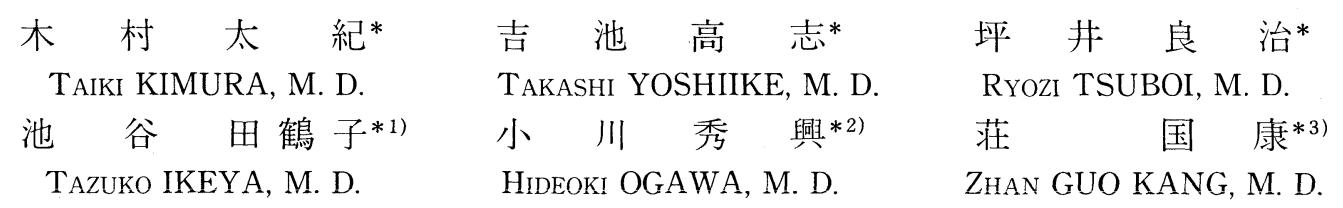

各種の湿疹患者に対して卋味敗毒湯を投与しその効果をみた。対象は29例であり,これら の患者に対し 12 週間十味敗毒湯を服用せしめた。効果発現は $66 \%$ にられた。なお効果発現 迄の時期は平均 5 週であったが, 効果の大なるもの程, 発現時期は早かった.

ステロイド剂を服用している患者で効果がみられた患者 5 名においては，ステロイド剤の 内服の中止又は減量が可能となった。

副作用はごく数例にみられたが重篤なものはみられなかった。

以上の結果より，十味敗毒湯は，湿疹に対し極めて有効であると思われる.

索引用語：十味敗毒湯, 慢性湿疹, ステロイド療法

Key words : Jumihaidokuto, chronic eczema, corticosteroid therapy

\section{はじめに}

皮膚疾患中かなりの頻度を占める湿疹類の治療 の主体は，ステロイド剂の外用である。現在，各 種ステロイド剂と種々な工夫をこらした基剤が 様々な組合せのもとに頻用されており，それらの 疾患或は病像への時宜をえた適応法により，多く の湿疹類は，まずコントロールされている。しか し乍ら，各種皮䖉疾患の治療上，長期にわたるス テロイド剂からの離脱が困難な場合や，ステロイ ド剤による副作用も問題となる場合が少なくない． この様な状況下で, 最近, 漢方薬の適応が再認識

* 順天堂大学医学部皮膚科学教室: ${ }^{* 1)}$ 講師 *2)教授 *3)協力研究員

Department of Dermatology, Juntendo University School of Medicine, Tokyo, Japan

**第 1 回順天堂大学漢方学術講演〔Sept. 1, 1985〕 (June 14, 1985受付)
されつつある。我々は最近，梁味敗毒湯が主とし て, 湿疹類の治療の補助薬刘として, 特にステロ イドからの離脱上有効であるとの結果を得たので, その詳細について報告する。

\section{対象}

昭和 59 年 3 月より，昭和 59 年 12 月迄に，当皮虐 科で加療中か又は，新しく受診した患者で，西洋 医学の治療によく反応しなかった症例29例を対象 とした。内訳は, 尋常性湿疹19例, 脂漏性湿疹 2 例，貨幣状湿疹 2 例，アトピ一性皮膚炎 2 例，皮 脂欠乏性湿疹 4 例である。

\section{使用薬剂}

ツムラ十味敗毒湯エキス顆粒を使用した。この 成分は表 1 に示寸が，桔梗が，その成分のサポ二 ンにより排膿効果を示し，甘草は，他薬との併用 による增強作用を有し, 柴胡は鎮痛解熱効果を有 
表 1 ツムラ十味敗毒湯エキス顆粒

Tsumura Jumihaidokuto

\section{一般名}

十味敗毒湯 ジュウミハイドクトウ

\begin{tabular}{|c|c|c|}
\hline \multicolumn{3}{|l|}{ 組 成 } \\
\hline 日局キキョウ & （桔梗） & $3.0 \mathrm{~g}$ \\
\hline 日局サイコ & （柴胡） & $3.0 \mathrm{~g}$ \\
\hline 日局センキュウ & （川芦） & $3.0 \mathrm{~g}$ \\
\hline 日局ブクリョウ & （获苓） & $3.0 \mathrm{~g}$ \\
\hline 日局ボウフウ & （防風） & $1.5 \mathrm{~g}$ \\
\hline 日局カンゾウ & （甘草） & $1.0 \mathrm{~g}$ \\
\hline 日局ケイガイ & （荆芥） & $1.0 \mathrm{~g}$ \\
\hline 日局ショウキョウ & （生姜） & $1.0 \mathrm{~g}$ \\
\hline ボクソク & （樸樕） & $3.0 \mathrm{~g}$ \\
\hline ドッカツ & (独活) & $1.5 \mathrm{~g}$ \\
\hline
\end{tabular}

本品 $5.0 \mathrm{~g}$ 中には, 上記の割合の混合生薬より得た乾燥工 キス粉末 $2.0 \mathrm{~g}$ を含有する。

し，紅斑消除が期待される。藋莽，防風，独活は， 袪風上痒効果を有する。养樕は収れん剂, 川芦, 生 姜は, 補血剤である。以上十種の生薬が配合さ れて，皮膚の発赤，腫張，瘁痒などを鎮め，化膿 性炎症を抑える効果を有する。

\section{投与量と投与法}

1 日量 $7.5 \mathrm{~g}$ を 3 回食前に服用させる. 投与期間 は12週を目標とした。なお，服用開始前にステロ イド軟膏，ステロイド内服剂，抗ヒスタミン剂等 の投与をうけていた患者にはひき続き使用を許可 した。ただし併用薬は，十味敗毒湯を使用前に， 少なくとも 4 週間使用させた症例を集計した。観 察は, 2 週間毎に行い, 瘙痒, 潮紅, 丘疹, 水疱, びらん，鱗屑，浸潤，肥厚のそれぞれの程度を， 5 段階に分けて, 観察し, 投与前のそれと比較し, それにより改善度を 5 段階に判定した。更に皮疹 改善度とあわせ, 副作用の有無, ステロイドより の離脱ができたか等を総合的に評価した。

\section{臨床 成 績}

対象症例は29例で，その内脱落例が 4 例である. 脱落例 4 例のうち, 1 例 (NO.26) は 8 週迄, 2 例（NO. 27，28）は 4 週迄経過を追跡しえた（表 2 ). 他の症例は，12週にわたり投与を続けること ができた。表に示す如く，“極めて有用”は 3 例 $(12 \%)$, “有用”は 6 例 $(23 \%)$, “やや有用”

表 2 十味敗毒湯投与臨床成績

\begin{tabular}{|c|c|c|c|c|c|c|c|c|c|c|c|c|c|c|c|c|c|}
\hline 症 & \begin{tabular}{|l|} 
年 \\
齢
\end{tabular} & 性 & $\begin{array}{l}\text { 体 } \\
\text { 重 }\end{array}$ & $\begin{array}{l}\text { 身 } \\
\text { 長 }\end{array}$ & 病 & 重症度 & 副作用 & 効 果 & 症 & $\begin{array}{l}\text { 年 } \\
\text { 齢 }\end{array}$ & 性 & $\begin{array}{l}\text { 体 } \\
\text { 重 }\end{array}$ & $\begin{array}{l}\text { 身 } \\
\text { 長 }\end{array}$ & 病 & 重症度 & 副作用 & 効 果 \\
\hline 1 & 65 & $\mathrm{~F}$ & 48 & 152 & 皮脂欠乏性湿疹 & 中 & なし & 不変 & 16 & 42 & $\mathrm{M}$ & 65 & 170 & 慢性湿疹 & 中 & なし & 不変 \\
\hline 2 & 45 & $\mathrm{~F}$ & 49 & 155 & " & 重 & $"$ & 有用 & 17 & 63 & $\mathrm{~F}$ & 55 & 153 & " & " & 下痢 & $" \prime$ \\
\hline 3 & 84 & $\mathrm{M}$ & 55 & 162 & $" \prime$ & 中 & $\prime \prime$ & 極めて有用 & 18 & 45 & $\mathrm{~F}$ & 51 & 158 & $" \prime$ & " & なし & やや有用 \\
\hline 4 & 85 & $\mathrm{~F}$ & 42 & 155 & $" 1$ & $\prime \prime$ & " & 不変 & 19 & 71 & $\mathrm{~F}$ & 55 & 168 & $" \prime$ & $"$ & 药麻疹(?) & 不変 \\
\hline 5 & 18 & $\mathrm{~F}$ & 43 & 158 & 貨幣状湿疹 & 重 & 上腹部痛 & " & 20 & 57 & $\mathrm{~F}$ & 40 & 158 & " & 重 & 肝機能異常 & やや有用 \\
\hline 6 & 47 & $\mathrm{~F}$ & 69 & 177 & $"$ & 中 & なし & " & 21 & 59 & $\mathrm{M}$ & 65 & 168 & $\prime \prime$ & 中 & なし & 有用 \\
\hline 7 & 16 & $\mathrm{M}$ & 58 & 163 & アトピー性皮鬳炎 & 重 & $" 1$ & やや有用 & 22 & 70 & $\mathrm{M}$ & 88 & 163 & $\prime \prime$ & 中 & $"$ & 極めて有用 \\
\hline 8 & 29 & $\mathrm{M}$ & 59 & 169 & " & 中 & $"$ & 不変 & 23 & 64 & $\mathrm{~F}$ & 45 & 152 & " & 重 & $"$ & やや有用 \\
\hline 9 & 23 & $\mathrm{~F}$ & 50 & 162 & 慢性湿疹 & 中 & $"$ & やや有用 & 24 & 79 & $\mathrm{~F}$ & 45 & 157 & " & 中 & $" 1$ & 有用 \\
\hline 10 & 60 & $\mathrm{M}$ & 55 & 165 & " & $" \prime$ & $"$ & $\prime \prime$ & 25 & 63 & $\mathrm{~F}$ & 49 & 152 & " & 重 & $" \prime$ & " \\
\hline 11 & 66 & $\mathrm{~F}$ & 45 & 152 & $"$ & $" 1$ & $" \prime$ & 有用 & 26 & 64 & $\mathrm{M}$ & 56 & 165 & " & 中 & $" \prime$ & $" 1$ \\
\hline 12 & 53 & $\mathrm{~F}$ & 47 & 153 & $\prime \prime$ & 重 & 菇麻疹(?) & 不変 & 27 & 15 & $\mathrm{~F}$ & 47 & 158 & " & $"$ & $" 1$ & 不明 \\
\hline 13 & 83 & $\mathrm{~F}$ & 40 & 158 & $\prime \prime$ & $\prime \prime$ & なし & 極めて有用 & 28 & 46 & $\mathrm{~F}$ & 46 & 152 & " & 重 & $"$ & " \\
\hline 14 & 69 & $\mathrm{~F}$ & 71 & 152 & $" \prime$ & 中 & $" \prime$ & やや有用 & 29 & 61 & $\mathrm{M}$ & 65 & 168 & " & 中 & $"$ & $"$ \\
\hline 15 & 44 & $\mathrm{M}$ & 72 & 171 & $\prime \prime$ & 重 & $\prime \prime$ & やや有用 & & & & & & & & & \\
\hline
\end{tabular}


表 3 疾患別臨床成績

\begin{tabular}{|c|c|c|c|c|}
\hline & 不変 & やや有用 & 有用 & 極めて有用 \\
\hline \multirow{2}{*}{ 皮脂欠乏性湿疹 } & $50 \%$ & $0 \%$ & $25 \%$ & $25 \%$ \\
\hline & $(2 / 4)$ & $(0 / 4)$ & $(1 / 4)$ & $(1 / 4)$ \\
\hline \multirow{2}{*}{ 貨幣状湿疹 } & $100 \%$ & $0 \%$ & $0 \%$ & $0 \%$ \\
\hline & $(2 / 2)$ & $(0 / 2)$ & $(0 / 2)$ & $(0 / 2)$ \\
\hline \multirow{2}{*}{ アトピー性皮䖉炎 } & $50 \%$ & $50 \%$ & $0 \%$ & $0 \%$ \\
\hline & $(1 / 2)$ & $(1 / 2)$ & $(0 / 2)$ & $(0 / 2)$ \\
\hline \multirow{2}{*}{ 慢 性 湿 疹 } & $23 \%$ & $39 \%$ & $27 \%$ & $11 \%$ \\
\hline & $(4 / 18)$ & $(7 / 18)$ & $(5 / 18)$ & $(2 / 18)$ \\
\hline 計 & $34 \%$ & $31 \%$ & $23 \%$ & $12 \%$ \\
\hline
\end{tabular}

は 8 例 $(31 \%)$ ，“不変”は 9 例 $(34 \%)$ であった。 有用であったものは総計 $66 \%$ であった。疾患別に みると, 皮脂欠乏性湿疹では, 有用が 2 例 $(50 \%)$, 貨幣状湿疹では，有用例なく，アトピー 性皮膚炎では有用例 1 例 (50\%)，慢性湿疹では有 用が14例 $(77 \%)$ であった。これらの結果を表 3 に示す，体格によって症例を分けて見ると，やせ 型では有用が $4 / 6(66 \%)$ ，中等度体格では有

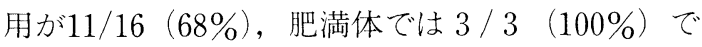
あり，やせ型では効果が少ない。

表 4 は治療経過を示したもので, 治療効果がみ られる時期は平均 5 週目であり, “やや有用”群で は 6 週頃, “有用”群では 4 週頃, “極めて有用” 群は 2 週頃であり, 効果が大きい群では, 効果 出現の時期も早い。また副腎皮質ホルモンを内服 している患者では, ステロイド剤の減量, 離脱を 試みたが，表 4 に示す如く，3 例が減量に 2 例が 中止に成功している。

\section{副作 用}

十味敗毒湯は，長期連用により，時に，偽アル ドステロン症がみられるという。我々の経験では, 副作用としては，上腹部痛 1 例（症例 5 ), 下痢

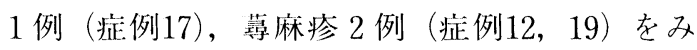
た。血液検查にて異常を示した例はみられなかっ た。器麻疹の 2 例は, 過去にその既忍はみとめら れないが，真の副作用か否かは定かではない。
表 4 治療経過表

\begin{tabular}{|c|c|c|c|c|c|c|c|c|}
\hline $\begin{array}{l}\text { 症 } \\
\text { 例 }\end{array}$ & 効 果 & 2 週 & $\begin{array}{l}\text { 臨 } \\
4 \text { 週 }\end{array}$ & $\begin{array}{l}\text { 床 } \\
6 \text { 週 }\end{array}$ & $\begin{array}{l}\text { 経 } \\
8 \text { 週 }\end{array}$ & $\begin{aligned} \text { 過 } \\
10 \text { 週 }\end{aligned}$ & 12週 & $\begin{array}{l}\text { ステロイド内服 } \\
\text { 薬の減量, 離脱 }\end{array}$ \\
\hline 7 & やや有用 & - & - & - & + & + & + & \\
\hline 9 & " & - & - & - & + & - & + & $\begin{array}{l}\text { セレスタミン } \\
2 \mathrm{~T} \rightarrow 2 \mathrm{~T}\end{array}$ \\
\hline 10 & $" \prime$ & - & + & + & + & + & + & \\
\hline 14 & $" 1$ & - & + & + & + & + & + & $\begin{array}{l}\text { セレスタミン } \\
2 \mathrm{~T} \rightarrow 1 \mathrm{~T}\end{array}$ \\
\hline 15 & $"$ & - & - & + & + & + & - & $\begin{array}{l}\text { セレスタミン } \\
2 \mathrm{~T} \rightarrow 2 \mathrm{~T}\end{array}$ \\
\hline 18 & "I & - & + & + & + & $H$ & + & \\
\hline 20 & " & - & + & + & + & - & + & \\
\hline 23 & " & - & - & - & - & + & + & \\
\hline 2 & 有 用 & + & + & $\#$ & $H$ & H & H & $\begin{array}{l}\text { セレスタミン } \\
2 \mathrm{~T} \rightarrow 0\end{array}$ \\
\hline 11 & $"$ & + & + & + & + & H & $H$ & \\
\hline 21 & " & - & - & + & + & H & \# & \\
\hline 24 & "I & $x$ & - & \# & H & $H$ & - & \\
\hline 25 & " & - & + & $H$ & + & $\#$ & H & \\
\hline 26 & " & - & + & + & + & & & $\begin{array}{l}\text { セレスタミン } \\
2 \mathrm{~T} \rightarrow 0\end{array}$ \\
\hline 3 & 橄めて有用 & + & + & + & - & \# & 世 & \\
\hline 13 & 11 & + & H & H & H & H & H & \\
\hline 22 & $" 1$ & + & H & H & H & H & $H$ & \\
\hline
\end{tabular}

\#：著明改善, + ：改善, + ：やや改善 - : 不変, $\times$ : 悪化

\section{考按}

近年，漢方療法が注目をあびているが，漢方に よる治療は，元来“証”にもとづいて，処方して いくという方法をとる。証があわなければ，治癒 は望めないことになる。しかし漢方の素養のない 医師にとって証を正しく把握することは容易では ない, そこで最近は, 西洋医学流に証によらず, 病名により投与を行っていく方法もとられる様に なった。

今回使用した十味敗毒湯は, 体力が中等度以上 で患部が乾燥し, 分泌が少ない湿疹, 萇麻疹に使 用される。

中井（太）らは，薄麻疹に対し，十味敗毒湯を 使用し，有効率 $66 \%$ と報告している，彼等の報告 でも効果発現には，1２週を要している。

副作用に関しては，中井（太）らは呕気が26例 
中 1 例，大塚（敬）は筋肉痛の生ずる場合がある と述べている，我々の場合も，副作用の発現は前 述した様に 4 例にみられたが，重篤なものはみら れなかった。

副作用の少なさと，高い効果発現率からみて， 十味敗毒湯は大変有用であると思われる。

\section{文献}

1. AJD 漢方研究会 張明澄監修: 中国漢方事典, 第 一通社, 1976

2. 中井太一, 他：器麻疹に対する十味敗毒湯の治療効 果. 臨床と研究, 59 : 123 125，1981

3. 大塚敬節：症候による漢方治療の実際。南山堂, 1972

4. 坂口弘：漢方処方の副作用. 漢方の臨床, 19 : $326 \sim 330,1972$

5. 藤井健 : 漢方の副作用について. 漢方の臨床, $19: 127 \sim 129,1972$

\section{Summary}

\section{Clinical Effect of Jumihaidokuto(Tsumura) on Eczema}

We used Jumihaidokuto (Tsumura) for the patients of several kinds of eczema. The number of patients is 29 : chronic eczema 21, atopic dermatitis 2 , annular eczema 2 , xerotic eczema 4 . In 13 patients, improvements were observed, and further more, in 5 patients oral administration of corticosteroid could be stopped or the dosis of it could be redued.

The occureuce of side effects is very rare, (epigastralgia 1 , diarrhea 1 , urticaria 2 ). We think that Jumihaidokuto is very effective for the dermatitis patients.

Key words : Jumihaidokuto, chronic eczema, cortico steroid therapy

TAIKI KIMURA, M. D., TAKashi YOSHIIKE, M. D., Ryozi TSUBOI, M. D., TAZUKo IKEYA, M. D., Hideoki OGAWA, M. D., Zhan GUO KANG, M. D.

Department of Dermatology, Juntendo University School of Medicine, Tokyo, Japan 